\title{
ORGANIC PHOSPHORUS FRACTIONS IN SOIL FERTILIZED WITH CATTLE MANURE
}

\author{
Lucas Boscov Braos(1), Mara Cristina Pessôa da Cruz(2), Manoel Evaristo Ferreira(2)* and \\ Fernando Kuhnen(1)
}

(1) Universidade Estadual Paulista, Faculdade de Ciências Agrárias e Veterinárias, Programa de Pós-graduação em Agronomia (Ciência do Solo) - bolsistas Fapesp, Jaboticabal, São Paulo, Brasil.

(2) Universidade Estadual Paulista, Faculdade de Ciências Agrárias e Veterinárias, Departamento de Solos e Adubos, Jaboticabal, São Paulo, Brasil.

* Corresponding author.

E-mail: evaristo@fcav.unesp.br

\begin{abstract}
Inorganic phosphorus (Pi) usually controls the $\mathbf{P}$ availability in tropical soils, but the contribution of organic $P$ (Po) should not be neglected, mainly in systems with low $P$ input or management systems that promote organic matter accumulation. The aims of this study were to evaluate the changes in the Po fractions over time in soil fertilized and not fertilized with cattle manure and to correlate Po forms with available $\mathbf{P}$ extracted by anion exchange resin. The experiment was carried out under field conditions, in a sandy-clay loam Haplustox. The experimental design was a $2 \times 9$ randomized complete block factorial design, in which the first factor was manure application $\left(20 \mathrm{t} \mathrm{ha}^{-1}\right)$ or absence, and the second the soil sampling times $(3,7,14,21,28,49,70,91$, and 112 days) after manure incorporation. Labile, moderately labile and non-labile Po fractions were determined in the soil material of each sampling. Manure fertilization increased the Po levels in the moderately labile and non-labile fractions and the total organic $\mathbf{P}$, but did not affect the Po fraction proportions in relation to total organic $\mathbf{P}$. On average, $5.1 \%$ of total Po was in the labile, $44.4 \%$ in the moderately labile and $50.5 \%$ in the non-labile fractions. Available P (resin P) was more affected by the manure soluble Pi rather than by the labile Po forms. The labile and non-labile Po fractions varied randomly with no defined trend in relation to the samplings; for this reason, the data did not fit any mathematical model.
\end{abstract}

Keywords: labile organic $\mathrm{P}$, moderately labile organic $\mathrm{P}$, non-labile organic $\mathrm{P}$, resin $\mathrm{P}$. 


\title{
RESUMO: FRAÇÕES DO FÓSFORO ORGÂNICO EM SOLO ADUBADO COM ESTERCO BOVINO
}

\begin{abstract}
O fósforo inorgânico (Pi) normalmente comanda a disponibilidade do P nos solos tropicais; entretanto, a contribuição do Porgânico (Po) não pode ser desconsiderada, principalmente em áreas com baixa entrada de Pou em sistemas de manejo que favoreçam o acúmulo de matéria orgânica. Os objetivos deste trabalho foram avaliar as transformações do P orgânico em solo adubado com esterco bovino e correlacionar as formas de Po com o $P$ disponivel extraído por resina trocadora de ânions. $O$ experimento foi conduzido em condições de campo, em Latossolo Vermelho de textura média. As amostras de solo usadas no fracionamento do Po foram coletadas nas parcelas do experimento que receberam 0 e $20 \mathrm{t} \mathrm{ha-1}$ de esterco, em nove épocas de amostragem (3, 7, 14, 21, 28, 49, 70, 91 e 112 dias após a incorporação do esterco bovino), de modo que os dados foram analisados considerando esquema fatorial $2 \times 9$, em parcelas subdivididas, em que as doses foram os tratamentos principais e as épocas de amostragem, os tratamentos secundários. Nas amostras coletadas em cada tempo de amostragem, foram feitas as determinações de Po lábil, moderadamente lábil e não lábil. A aplicação do esterco aumentou o Po moderadamente lábil, o Po não lábil e o Po total e não interferiu nas proporções das frações em relação ao Po total. Em média, 5,1\% do Po total estavam na fração lábil; 44,4 \%, na fração moderadamente lábil; e 50,5\%, na fração não lábil. As formas de Pi mais solúveis do esterco influenciaram mais na fração disponível para as plantas (P resina) do que as formas lábeis de Po. As frações Po lábil e Po não lábil variaram em relação ao tempo, mas com aumentos e diminuições aleatórios, de modo que modelos matemáticos não se ajustaram aos dados.
\end{abstract}

Palauras-chave: P orgânico lábil, P orgânico moderadamente lábil, $P$ orgânico não lábil, $P$ resina.

\section{INTRODUCTION}

Soils contain inorganic $\mathrm{P}(\mathrm{Pi})$ and organic $\mathrm{P}(\mathrm{Po})$ compounds that are important $\mathrm{P}$ sources for plants, but Po rarely represents a major portion of soil P. In a research with tropical forest soils (Oxisols, Ultisols, Alfisols, and Inceptisols), the Po fraction represented $26 \pm 1 \%$ of total $\mathrm{P}$, distributed in phosphate monoesters (68-96\%), such as mononucleotides and inositol phosphate, and phosphate diesters (4-32\%), mainly in form of nucleic acids and phospholipids (Turner and Engelbrecht, 2011).

In natural or agricultural ecosystems on low $\mathrm{P}$ soils, Po mineralization is the main source of $\mathrm{P}$ supply to plants, especially in highly weathered tropical soils (Vincent et al., 2010). The conversion of natural ecosystems into cropland alters the soil $\mathrm{P}$ forms and quantities available to plants. Usually, Po decreases rapidly in agricultural systems, especially in the absence of $\mathrm{P}$ fertilization, simultaneously with a fast decrease in soil organic $\mathrm{C}$ and total $\mathrm{P}$ levels (Conte et al., 2002). The contribution of soil Po to increase available $\mathrm{P}$ (labile $\mathrm{P}$ ) can be more relevant when organic fertilization or other practices that increase the soil organic matter content $(\mathrm{OM})$ are part of the soil management.

Organic fertilization affects the $\mathrm{P}$ availability directly and indirectly. The direct effects include: Pi release by organic compound mineralization (Hue et al., 1994) or microbial immobilization of soil Pi (Chen et al., 2000), depending on the $\mathrm{C} / \mathrm{P}$ ratio; competition between organic acid anions and phosphate anions for adsorption sites (Andrade et al., 2003; Guppy et al., 2005);
Pi compound dissolution by organic acids; and metal complexation, particularly of $\mathrm{Al}^{3+}$ and $\mathrm{Fe}^{2+}$ (Andrade et al., 2003), with lower phosphate anion precipitation reactions. The indirect effects of organic fertilization on $\mathrm{P}$ availability are improvements in soil physical properties, resulting in better root development and soil $\mathrm{pH}$ increase (Eghball, 2002). Although the $\mathrm{pH}$ increase is an indirect effect observed after manure application, it is an important factor contributing to $\mathrm{P}$ availability to plants. The cause for this $\mathrm{pH}$ increase is the presence of $\mathrm{Ca}$ and the buffer effect of bicarbonate and organic acid anions (carboxylic, phenolic and hydroxylic groups) (Sharpley and Moyer, 2000). However, the increase in $\mathrm{pH}$ values is only observed when large amounts of manure are applied to the soil, and in spite of being a short-term effect, it might affect $P$ availability.

Cattle, swine and poultry manure are some of the most promising organic fertilizers for soil application. Total $\mathrm{P}$ concentrations vary largely among the different organic manures, depending on the livestock and livestock management. The $\mathrm{P}$ concentrations in cattle manure usually range from 4.5 to 14.2 and 2.8 to $15.0 \mathrm{~g} \mathrm{~kg}^{-1} \mathrm{P}$ for the meat and milk production managements, respectively (Pagliari and Laboski, 2012).

Most $\mathrm{P}$ in cattle manure is found in inorganic form. Data from 11 composite samples containing mostly fresh dairy manure showed $71 \pm 3.6 \%$ of total P as inorganic P (Pi) (Darch et al., 2014). The $\mathrm{Pi}$ fraction consists predominantly of water-soluble compounds, mainly with $\mathrm{Ca}$, with a bonding energy that varies according to the physical-chemical 
conditions, but tends to be more stable in composted manure (Dou et al., 2000). The presence of Ca and $\mathrm{Mg}$, associated with $\mathrm{pH}$ values higher than 7.0, which is common in manures, induce the formation of low solubility compounds that react more slowly in the soil than the soluble fertilizers (Sharpley and Sisak, 1997). Nevertheless, the P present in the organic compounds is not readily available to plants, but part of it may be mineralized during plant growth and, thus, become available.

Acid and alkaline extractors are used to characterize the soil Po fractions, which are able to separate fractions based on the type and energy of physical-chemical interaction between Po and the soil components (Bowman and Cole, 1978; Hedley et al., 1982). The most commonly used extractors for Po fractionation are the $0.5 \mathrm{~mol} \mathrm{~L}^{-1}$ sodium bicarbonate $\left(\mathrm{NaHCO}_{3}\right)$ and hydrochloric acid $(\mathrm{HCl})$ and sodium hydroxide $(\mathrm{NaOH})$ at different concentrations. The Po fractionation separates the labile, moderately labile and non-labile fractions and allows evaluating Po transformations under several soil types and management conditions (Hedley et al., 1982; Ivanoff et al., 1998). Data obtained in a highly weathered soil, cultivated during 18 years without addition of $\mathrm{P}$ fertilizer, showed that the Pi fraction extracted with $\mathrm{NaOH}$ acted as the system $\mathrm{P}$ sink, meanwhile the $\mathrm{Po}_{0}$ fraction extracted with the same extractor was the main P source to the plants (Beck and Sanchez, 1994). In a 30 year-long-term experiment with continuous manure application there was increase in total organic- $\mathrm{C}$, total $\mathrm{P}$ and in all $\mathrm{Po}$ forms extracted with $0.5 \mathrm{~mol} \mathrm{~L}^{-1} \mathrm{NaHCO}_{3}, 1.0 \mathrm{~mol} \mathrm{~L}^{-1} \mathrm{HCl}$ and $0.1 \mathrm{~mol} \mathrm{~L}^{-1} \mathrm{NaOH}$ (Hao et al., 2008).

Time is an important factor for Pi transformations in the soil and the Pi available fraction, as well as for Po transformations. With regard to Po, after the rapid initial phase of decomposition of organic residues applied to the soil, when $\mathrm{P}$ release and available $\mathrm{P}$ increases, it is expected that more stable (or recalcitrant) Po fractions could remain in the soil, and that part of the labile Po is converted to non-labile Po. In a soil incubation trial in laboratory, the application of swine manure caused an initial increase of water-soluble $\mathrm{P}$ concentrations, but after 16 weeks of incubation, water soluble $\mathrm{P}$ decreased with simultaneous increase of the $\mathrm{P}-\mathrm{NaHCO}_{3}$ fraction. Moreover, the application of cattle manure decreased soluble $\mathrm{P}$, while other more stable $\mathrm{P}$ forms increased, suggesting that microorganisms transformed labile-Pi into $\mathrm{Po}$, due to the higher amount of grass residues and higher $\mathrm{C} / \mathrm{P}$ ratio in the manure (Kashem et al., 2004).

The maintenance of adequate amounts of $\mathrm{P}$ in the soil through organic and inorganic fertilizer applications is critical for the long-term sustainability of agricultural systems. A clearer understanding of the nature, distribution and solubility of $\mathrm{P}$ forms in soil, identifying them and relating them to the extractants and the levels obtained may provide important information for the evaluation process of $\mathrm{P}$ availability for plants and to enhance the fertilizer management (Machado et al., 1993; Sharpley et al., 2004).

Therefore, the objectives of this study were to evaluate changes in the Po fractions over time in soil fertilized and not fertilized with cattle manure and to correlate Po forms with available $\mathrm{P}$ extracted by anion exchange resin.

\section{MATERIAL AND METHODS}

Soil samples from a field experiment with cattle manure application in Jaboticabal, State of São Paulo, Brazil, were subjected to organic $\mathrm{P}(\mathrm{Po})$ fractionation. The regional climate is type Aw, according to the Köppen classification, and the soil is a sandy-clay loam Haplustox. Soil chemical analysis (according to Raij et al., 2001) of samples collected before the experiment, from the $0-20 \mathrm{~cm}$ layer, contained: $\mathrm{P}_{\text {resin }}: 15 \mathrm{mg} \mathrm{dm}^{-3}$; OM: $16 \mathrm{~g} \mathrm{dm}^{-3} ; \mathrm{pH}\left(\mathrm{CaCl}_{2}\right): 5.5$; $\mathrm{K}^{+}: 1.2 \mathrm{mmol}_{\mathrm{c}} \mathrm{dm}^{-3} ; \mathrm{Ca}^{2+}: 22 \mathrm{mmol}_{\mathrm{c}} \mathrm{dm}^{-3} ; \mathrm{Mg}^{2+}$ : $11 \mathrm{mmol}_{\mathrm{c}} \mathrm{dm}^{-3} ; \mathrm{H}+\mathrm{Al}: 22 \mathrm{mmol}_{\mathrm{c}} \mathrm{dm}^{-3} ; \mathrm{SB}: 34 \mathrm{mmol}_{\mathrm{c}} \mathrm{dm}^{-3}$; CEC: $56 \mathrm{mmol}_{\mathrm{c}} \mathrm{dm}^{-3}$; V: $61 \%$. The soil particle size analysis (according to Camargo et al., 2009) results were: $340 \mathrm{~g} \mathrm{~kg}^{-1}$ clay, $20 \mathrm{~g} \mathrm{~kg}^{-1}$ silt and $640 \mathrm{~g} \mathrm{~kg}^{-1}$ sand.

The chemical characteristics of cattle manure, determined according to Alcarde (2009), were as follows after a six-month period of stabilization: $\mathrm{pH}\left(\mathrm{CaCl}_{2}\right): 6.9 ; \mathrm{C}_{\text {org }}: 260 \mathrm{~g} \mathrm{~kg}^{-1}$; insoluble mineral matter: $350 \mathrm{~g} \mathrm{~kg}^{-1}$; total $\mathrm{N}$ : $11.0 \mathrm{~g} \mathrm{~kg}^{-1}$ and $\mathrm{C} / \mathrm{N}$ ratio: 24; total P: $1.1 \mathrm{~g} \mathrm{~kg}^{-1}$ and $\mathrm{C} / \mathrm{P}$ ratio: 236 . The cattle manure samples were subjected to $\mathrm{P}$ fractionation, according to Dou et al. (2000), with the following results: $64 \%$ of $\mathrm{Pi}$ and $35 \%$ of $\mathrm{Po}$, and $1 \%$ of residual-P fraction in which the organic and inorganic forms were not identified (Table 1). The $\mathrm{pH}$ values were determined in fresh samples and all other results on a dry matter basis $\left(65^{\circ} \mathrm{C}\right)$.

For Po fractionation, soil samples from treatments with and without cattle manure (0 and $\left.20 \mathrm{t} \mathrm{ha}^{-1}\right)$ were collected during nine periods with four replications. The experiment started with manual cattle manure distribution ( 0 and $\left.20 \mathrm{t} \mathrm{ha}^{-1}\right)$ on the soil, followed by incorporation with a hoe into the $0 \pm 18 \mathrm{~cm}$ layer. After incorporation, furrows spaced $0.8 \mathrm{~m}$ between lines were opened with the hoe, and maize seeds were sown by hand. After sowing, PVC tubes $(7 \mathrm{~cm}$ diameter $\times 22 \mathrm{~cm}$ height) were installed between the rows to collect undisturbed soil samples on the scheduled dates for Po fractionation. Eighteen PVC tubes were inserted to a depth of $20 \mathrm{~cm}$ into the soil, in three of the six rows of the plot area. Two tubes were collected per sampling date, $3,7,14,21,28$, 49, 70, 91 and 112 days after manure incorporation 
Table 1. Inorganic (Pi) and organic (Po) $\mathrm{P}$ fractions of cattle manure

\begin{tabular}{lcccccc}
\hline P form & $\mathbf{P}_{\mathrm{H}_{2} \mathrm{O}}$ & $\mathbf{P}_{\mathrm{NaHCO}_{3}}{ }^{\left({ }^{2}\right.}$ & $\mathbf{P}_{\mathrm{NaOH}^{(2)}}$ & $\mathbf{P}_{\mathrm{HCl}^{(3)}}$ & $\mathbf{P}_{\text {residual }}{ }^{(4)}$ & Total P \\
\cline { 2 - 7 } & \multicolumn{7}{c}{$\mathrm{mg} \mathrm{kg}^{-1}$} \\
$\mathrm{Pi}$ & 476.8 & 265.2 & 86.9 & 18.4 & - & 847.3 \\
Po & 137.2 & 119.1 & 189.3 & 16.1 & - & 461.7 \\
Total P & 614.0 & 384.3 & 276.2 & 34.6 & 12.7 & 1309.0 \\
\hline
\end{tabular}

(1) $0.5 \mathrm{~mol} \mathrm{~L}^{-1} \mathrm{NaHCO}_{3}$ solution; (2) $0.1 \mathrm{~mol} \mathrm{~L}^{-1} \mathrm{NaOH}$ solution; (3) $1.0 \mathrm{~mol} \mathrm{~L}-1$ HCl solution; (4) Obtained by nitric-perchloric digestion procedure, as used for total $\mathrm{P}$ determination.

and maize sowing. From each tube, soil subsamples of equal volume were mixed and then ground, dried and sieved through $2 \mathrm{~mm}$ mesh. After that, the procedure of Po fractionation was applied to the soil samples, according to Bowman and Cole (1978), modified by Ivanoff et al. (1998) and described by Kovar and Pierzynski (2009). This procedure allowed separating labile, moderately labile and non-labile Po forms (Figure 1). In each fraction, Po was calculated as the difference between total $\mathrm{P}$ and Pi concentrations, obtained in the same extract after digestion and before digestion, respectively. In the digestion procedure, $0.25 \mathrm{~g}$ potassium persulfate $\left(\mathrm{K}_{2} \mathrm{~S}_{2} \mathrm{O}_{8}\right)$ was used per sample. Humic acid-Po fraction was calculated by the difference between the humic+fulvic acid fraction and fulvic acid fraction. Moderately labile Po was computed as the sum of the HCl-Po fraction and fulvic acid fraction. Non-labile Po was obtained by the sum of humic acid $\mathrm{Po}$ and residual Po. Based on preliminary tests, the fractionation procedure was slightly modified, compared to the original method, as follows: dry soil sample instead of fresh soil sample; extraction time of $6 \mathrm{~h}$ with $0.5 \mathrm{~mol} \mathrm{~L}^{-1} \mathrm{NaHCO}_{3}$ solution instead of $16 \mathrm{~h}$; digestion extract with $0.25 \mathrm{~g}$ of potassium persulfate instead of $0.5 \mathrm{~g}$ per sample. The latter modification was to avoid interference with the $\mathrm{P}$ analysis by the colorimetry of Murphy and Riley (1962).

Aside from the Po fraction analyses, the following determinations were performed in the extracts: $\mathrm{pH}$ in $0.01 \mathrm{~mol} \mathrm{~L}^{-1} \mathrm{CaCl}_{2}$, OM content by colorimetry, and P-resin concentration according to Raij et al. (2001); total $\mathrm{P}$ by digestion with $\mathrm{H}_{2} \mathrm{SO}_{4}+\mathrm{H}_{2} \mathrm{O}_{2}+\mathrm{HF}$ and total organic $\mathrm{P}$ by incineration, according to Kuo (1996).

The statistical analysis was based on a $(2 \times 9)$ factorial design with split-plots. The two manure rates were the main treatments and the nine sampling dates the secondary treatments, with four replications. The data were subjected to analysis of variance ( $\mathrm{F}$ test). Treatment means were compared by the Tukey test (0.05), when significant variation was observed for the manure rates, and polynomial regression was applied to the sampling dates, in case of significant variation. Correlation analysis was applied to Po forms and OM, resin P, total Po and total $\mathrm{P}$ contents.

\section{RESULTS AND DISCUSSION}

The soil $\mathrm{pH}\left(\mathrm{CaCl}_{2}\right)$ values increased by 0.4 units with manure application (Table 2). This effect is well known and was already expected (Whalen et al., 2000; Eghball, 2002) and might be due to the bicarbonate anion $\left(\mathrm{HCO}_{3}^{-}\right)$buffer effect and other organic acids present in the cattle manure (Whalen et al., 2000) or formed during decomposition. The process involved is the same described for plant residue decomposition, that is, malate, citrate, oxalate and other organic acids are decomposed by microorganisms with simultaneous increase of soil $\mathrm{pH}$ due to the decarboxylation reaction in which protons are consumed and $\mathrm{CO}_{2}$ is released: $\mathrm{R}-\mathrm{CO}-\mathrm{COO}^{-}+\mathrm{H}^{+} \rightarrow \mathrm{R}-\mathrm{CHO}+\mathrm{CO}_{2}$ (Yan et al., 1996).

No differences were observed among treatments (manure application or increasing time of incubation) in OM contents (Table 2). In general, soil OM increase with manure or other organic residue application is only observed in longterm fertilization with successive applications (Viaud et al., 2011). In this experiment, the evaluations were performed 112 days of field incubation after a single manure application of $20 \mathrm{t} \mathrm{ha}^{-1}$. Yagi et al. (2003), in an experiment with cattle manure application of $70 \mathrm{t} \mathrm{ha}^{-1}$ (a 3.5-fold higher rate), observed an increase of $3.5 \mathrm{~g} \mathrm{dm}^{-3}$ of organic C after 180 days of incubation under laboratory conditions. Under field conditions, $\mathrm{OM}$ increases in this order are harder to obtain. In a temperate climate region, after 90 years of annual manure applications, the total soil organic C increased by $3.2 \mathrm{~g} \mathrm{~kg}^{-1}$ (Schjønning et al., 1994). This fact indicated that under field conditions, retention of manure- $\mathrm{C}$ in the soil OM is low, and estimates of long-term experiments determined a $\mathrm{C}$ retention coefficient of $12 \pm 4 \%$ (Maillard and Angers, 2014).

In the soil treated with manure the mean values of total $\mathrm{P}$ and resin $\mathrm{P}$ averaged over sampling time were higher (Table 2). The total $\mathrm{P}$ values found in this study (Table 2) exceeded the mean values reported for native (non-fertilized and non-cultivated) Oxisols (193 mg kg-1), but were within the range observed for 11 soil classes, that is, 193 and $903 \mathrm{mg} \mathrm{kg}^{-1} \mathrm{P}$ in Oxisols and Andisols, respectively (Yang and Post, 2011). The higher total $\mathrm{P}$ 


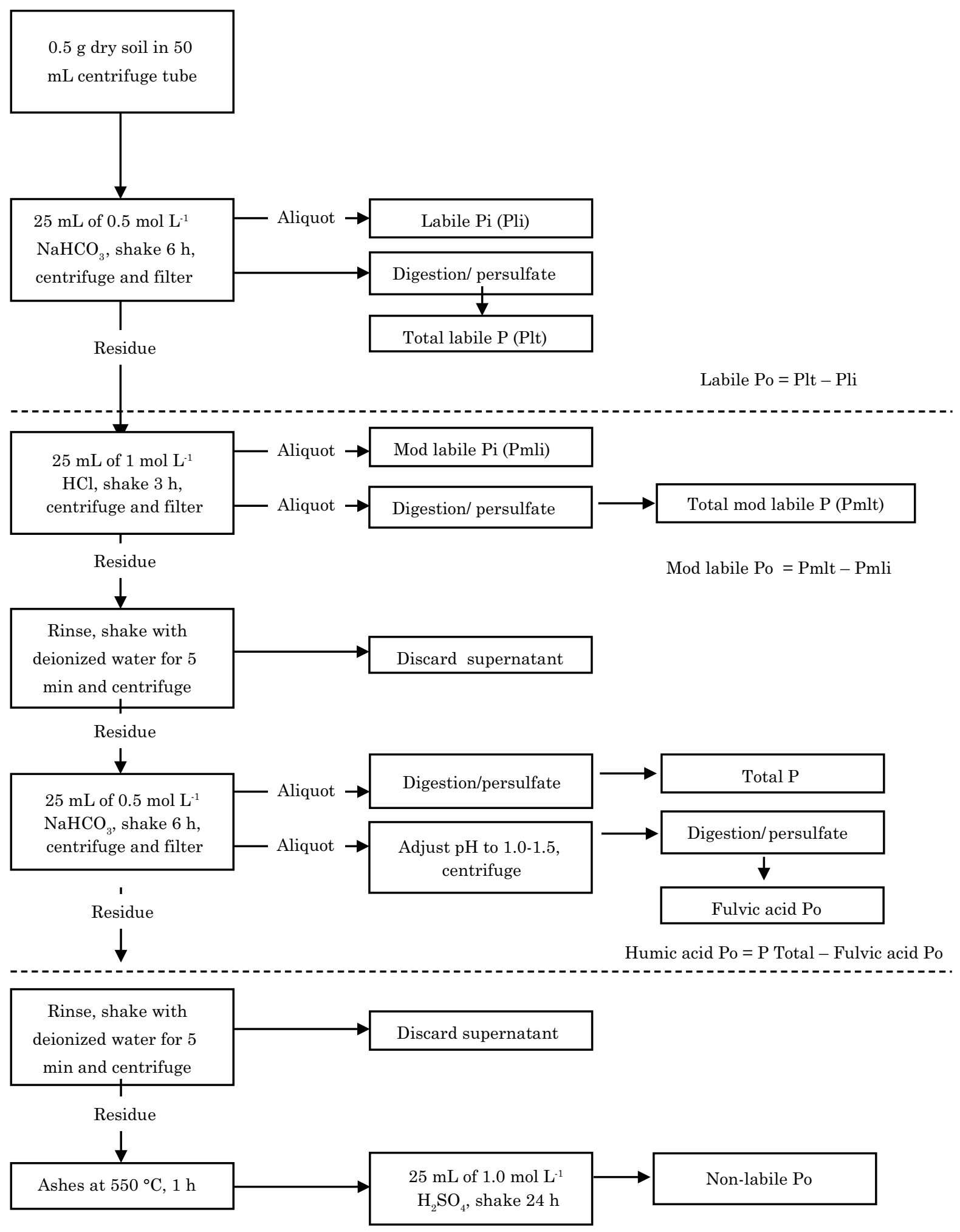

Figure 1. Organic $P$ fractionation procedure, according to Kovar and Pierzynski (2009), with modifications of soil sample weight and reagent volumes, but unaltered proportions.

observed in this work in samples of a sandy-clay loam Haplustox might be due to local differences of soil genesis and previous P-fertilizations in the area.
Other authors reported the effect of cattle manuring on the soil $\mathrm{P}$ concentration increase, measured by different extractants (Griffin et al., 2003; 
Table 2. Mean values of $\mathrm{pH}\left(\mathrm{CaCl}_{2}\right)$, organic matter $(\mathrm{OM})$, total $\mathrm{P}$ and resin $\mathrm{P}$ concentrations in a sandyclay loam Haplustox fertilized or not with cattle manure during increasing periods of incubation, until 112 days

\begin{tabular}{|c|c|c|c|c|c|c|c|c|c|c|}
\hline \multirow{2}{*}{ Manure } & \multicolumn{9}{|c|}{ Incubation time (day) } & \multirow{2}{*}{ Mean } \\
\hline & 3 & 7 & 14 & 21 & 28 & 49 & 70 & 91 & 112 & \\
\hline t ha-1 & \multicolumn{10}{|c|}{$\mathrm{pH}\left(\mathrm{CaCl}_{2}\right)$} \\
\hline 0 & 5.4 & 5.8 & 5.7 & 5.4 & 5.3 & 5.8 & 5.7 & 5.6 & 5.5 & $5.6 \mathrm{~b}$ \\
\hline \multirow[t]{2}{*}{20} & 5.9 & 6.2 & 6.0 & 5.8 & 6.0 & 6.1 & 6.2 & 6.1 & 6.0 & $6.0 \mathrm{a}$ \\
\hline & \multicolumn{10}{|c|}{$\mathrm{OM}\left(\mathrm{g} \mathrm{dm}^{-3}\right)$} \\
\hline 0 & 19 & 19 & 20 & 20 & 19 & 21 & 24 & 20 & 18 & $19.9 \mathrm{a}$ \\
\hline \multirow[t]{2}{*}{20} & 21 & 20 & 22 & 22 & 20 & 21 & 20 & 21 & 20 & $20.8 \mathrm{a}$ \\
\hline & \multicolumn{10}{|c|}{ Total P (mg kg-1) } \\
\hline 0 & 341 & 352 & 368 & 362 & 357 & 447 & 359 & 397 & 403 & $376.3 \mathrm{~b}$ \\
\hline \multirow[t]{2}{*}{20} & 417 & 404 & 410 & 436 & 404 & 447 & 454 & 434 & 341 & $417.8 \mathrm{a}$ \\
\hline & \multicolumn{10}{|c|}{ Resin P (mg dm-3) } \\
\hline 0 & 15 & 15 & 19 & 17 & 11 & 12 & 20 & 24 & 16 & $17.5 \mathrm{~b}$ \\
\hline 20 & 36 & 44 & 41 & 34 & 44 & 49 & 56 & 50 & 38 & $43.3 \mathrm{a}$ \\
\hline \multicolumn{11}{|c|}{$\mathrm{F}$ test } \\
\hline & \multicolumn{3}{|c|}{$\mathrm{pH}$ value } & \multicolumn{2}{|c|}{$\mathrm{OM}$} & \multicolumn{3}{|c|}{ Total P } & \multicolumn{2}{|c|}{ Resin P } \\
\hline Manure & \multicolumn{2}{|c|}{$11.01^{* *}$} & & \multicolumn{2}{|c|}{$2.32^{\mathrm{ns}}$} & \multicolumn{3}{|c|}{$13.04^{* *}$} & \multicolumn{2}{|c|}{$73.44^{* *}$} \\
\hline Time & \multicolumn{2}{|c|}{$0.41^{\mathrm{ns}}$} & & \multicolumn{2}{|c|}{$1.09 \mathrm{~ns}$} & \multicolumn{3}{|c|}{$2.05^{\mathrm{ns}}$} & \multicolumn{2}{|c|}{$1.01^{\mathrm{ns}}$} \\
\hline $\mathrm{M} \times \mathrm{T}$ & \multicolumn{2}{|c|}{$0.11^{\mathrm{ns}}$} & & \multicolumn{2}{|c|}{$1.06^{\mathrm{ns}}$} & \multicolumn{3}{|c|}{$1.30^{\mathrm{ns}}$} & \multicolumn{2}{|c|}{$0.52^{\mathrm{ns}}$} \\
\hline CV (\%) & \multicolumn{2}{|c|}{10.06} & & \multicolumn{2}{|c|}{12.55} & \multicolumn{3}{|c|}{12.27} & \multicolumn{2}{|c|}{43.12} \\
\hline
\end{tabular}

ns and **: non-significant and significant at $\mathrm{p}<0.01$, respectively. Means followed by the same letters do not differ by Tukey's test $(\mathrm{p}<0.05)$.

Hao et al., 2008). Similarly, an increase in total $\mathrm{P}$ was reported (Sharpley et al., 2004), and both the increase in available $\mathrm{P}$ as in total $\mathrm{P}$ occur by the addition of $\mathrm{P}$ present in manure, which despite the low concentrations (Sharpley and Moyer, 2000; Pagliari and Laboski, 2012), is eventually added in large quantities by the high rates of manure applications. Hao et al. (2008), in a 30-year long-term experiment, observed increases as high as $2,182 \mathrm{mg} \mathrm{kg}^{-1}$ of total $\mathrm{P}$ in plots treated yearly with a manure dose of $60 \mathrm{tha}^{-1}$. In the same experiment, with the same annual dose applied for 14 years followed by 16 years without manure application, the authors observed a total $\mathrm{P}$ concentration increase of $630 \mathrm{mg} \mathrm{kg}^{-1}$, compared to the control plots (without manure addition).

The increase in resin $\mathrm{P}$ with manure application (Table 2) might also be due to other effects of manure on $\mathrm{P}$ availability, such as $\mathrm{pH}$ increase and anion release during the decomposition process. As $\mathrm{pH}$ increases, the processes of phosphate adsorption and precipitation decrease and might result in higher $\mathrm{P}$ extraction by the ion exchange resin method (Whalen et al., 2000). Similarly, the organic anion release may lead to lower $\mathrm{P}$ adsorption by competition for the bond sites on the oxide surfaces. Furthermore, complexation of $\mathrm{Fe}^{2+}$ and $\mathrm{Al}^{3+}$ with simple organic substances released during decomposition might occur, with a consequent decrease of phosphate precipitation reactions (Hue et al., 1994).
Resin $\mathrm{P}$ did not vary over the sampling time (field incubation period) (Table 2). The anion exchange resins extract exclusively inorganic forms of $\mathrm{P}$ (Gatiboni et al., 2005). Therefore, as $36 \%$ of $\mathrm{P}$ in manure was present in water-soluble inorganic forms (Table 1), all added Pi was extracted three days after incubation. If the system had been treated with $\mathrm{Pi}$ only, decreasing resin $\mathrm{P}$ with time would be expected, due to the transformation of labile-P into non-labile P. However, as labile Po forms were present at a proportion of $19 \%$ of total $\mathrm{P}$ added (Table 1), it was inferred that resin $\mathrm{P}$ was partly maintained by the Po microbial transformations, and partly by the manure addition effect on $\mathrm{pH}$ and organic anion release, as discussed above.

Labile Po did not change with manure application (Table 3). Motavalli and Miles (2002) also observed similar results after 111 years of continuous manure application, with labile Po values varying from 22.5 to $23.0 \mathrm{mg} \mathrm{kg}^{-1}$. Although the effect of sampling time on labile Po values was significant by the $\mathrm{F}$ test (Table 3), the linear and quadratic regression analyses were not significant. This random variation occurred because labile $\mathrm{Po}$ is the most instable Po fraction, which becomes plant-available most easily (Hedley et al., 1982), mainly because it is available to soil microorganisms (Bowman and Cole, 1978). This labile Po fraction is subject to transformations that depend on the microbial 
activity, soil type, enzymatic activity, and climate conditions (Hedley et al., 1982; Beck and Sanchez, 1994). The labile Po recovered in this extraction came mainly from nucleic acids, phospholipids and sugar phosphate. These compounds are easy mineralizable, releasing available $\mathrm{P}$ relatively quickly, thus making it available to plants or soil microorganisms (Blake et al., 2003; Turner and Engelbrecht, 2011). Sharpley and Sisak (1997) reported that manure application increases microbial activity, causing initial $\mathrm{P}$ immobilization, but then is released to plants by mineralization. Hao et al. (2008) also demonstrated Po instability, who observed increasing labile Po values with increasing manure rates applied without irrigation, but stated no such trend under irrigation. Under irrigation, the labile Po fraction was unaltered or decreased, depending on the manure rate applied.
Therefore, Po is a dynamic fraction and labile Po does not accumulate, but is rapidly mineralized or transformed into more stable compounds (Darilek et al., 2010).

The lowest Po recovery was obtained with $\mathrm{HCl}$ solution as extractant (Table 3). In this extraction step, the soil sample is actually pre-treated with the main objective of $\mathrm{Pi}$ removal, in order to not interfere with the subsequent extractions (Ivanoff et al., 1998; Kovar and Pierzynski, 2009). Nevertheless, this extraction is included in the calculus of the moderately labile Po, because the $\mathrm{HCl}$ solution extracts Po from the OM-humic fraction and Po bound to organic- $\mathrm{Ca}, \mathrm{Al}$ compounds (Blake et al., 2003; Kovar and Pierzynski, 2009).

On the other hand, there was a significant effect of manure on the moderately labile and non-labile

Table 3. Organic P fractions in a sandy-clay loam Haplustox fertilized or not with cattle manure, evaluated during 112 days of incubation

\begin{tabular}{|c|c|c|c|c|c|c|c|}
\hline Time & $\mathrm{PoNaHCO}_{3}{ }^{(1)}$ & PoHCl & Fulvic acid Po & Mod labile Po $^{(2)}$ & Humic acid Po & Residual Po & Non-labile $\mathrm{Po}^{(3)}$ \\
\hline \multirow[t]{2}{*}{ day } & \multicolumn{7}{|c|}{$\mathrm{mg} \mathrm{kg}^{-1}$} \\
\hline & \multicolumn{7}{|c|}{ Without manure } \\
\hline 3 & 3.6 & 2.2 & 41.2 & 43.3 & 13.1 & 42.8 & 55.9 \\
\hline 7 & 3.0 & 3.2 & 46.7 & 49.8 & 14.9 & 48.8 & 63.7 \\
\hline 14 & 6.1 & 2.0 & 45.7 & 47.7 & 14.6 & 46.3 & 60.9 \\
\hline 21 & 6.7 & 1.9 & 38.9 & 40.9 & 8.6 & 37.2 & 45.8 \\
\hline 28 & 9.1 & 5.7 & 42.5 & 48.1 & 10.0 & 43.2 & 53.3 \\
\hline 49 & 4.5 & 2.9 & 51.4 & 54.3 & 8.1 & 46.2 & 54.3 \\
\hline 70 & 7.3 & 5.1 & 44.6 & 49.8 & 7.5 & 47.0 & 54.5 \\
\hline 91 & 6.7 & 1.9 & 46.8 & 48.7 & 7.8 & 44.2 & 51.9 \\
\hline 112 & 6.0 & 3.2 & 47.9 & 51.0 & 8.3 & 43.0 & 51.3 \\
\hline \multirow[t]{2}{*}{ Mean } & $6.1 \mathrm{a}$ & $3.1 \mathrm{a}$ & $45.1 \mathrm{~b}$ & $48.2 \mathrm{~b}$ & $10.0 \mathrm{a}$ & $44.3 \mathrm{~b}$ & $54.6 \mathrm{~b}$ \\
\hline & \multicolumn{7}{|c|}{$20 \mathrm{t} \mathrm{ha}^{-1}$ manure } \\
\hline 3 & 4.5 & 2.9 & 48.2 & 51.1 & 11.2 & 46.6 & 57.8 \\
\hline 7 & 5.0 & 2.5 & 51.7 & 54.2 & 13.7 & 56.8 & 70.5 \\
\hline 14 & 4.1 & 6.0 & 47.9 & 53.9 & 14.8 & 53.0 & 67.8 \\
\hline 21 & 8.5 & 2.9 & 46.7 & 49.6 & 12.7 & 46.2 & 59.0 \\
\hline 28 & 6.4 & 4.3 & 50.3 & 54.6 & 11.8 & 45.0 & 56.8 \\
\hline 49 & 4.6 & 3.3 & 45.8 & 49.2 & 9.4 & 47.5 & 56.9 \\
\hline 70 & 7.1 & 6.7 & 52.4 & 59.2 & 8.3 & 49.0 & 57.3 \\
\hline 91 & 7.8 & 2.2 & 47.0 & 49.2 & 19.0 & 49.1 & 68.0 \\
\hline 112 & 6.6 & 5.4 & 53.2 & 58.5 & 8.4 & 45.0 & 53.4 \\
\hline \multirow[t]{2}{*}{ Mean } & $6.0 \mathrm{a}$ & $4.0 \mathrm{a}$ & $49.4 \mathrm{a}$ & $53.3 \mathrm{a}$ & $12.3 \mathrm{a}$ & $48.7 \mathrm{a}$ & $60.8 \mathrm{a}$ \\
\hline & & & & $\mathrm{F}$ test & & & \\
\hline Manure & $0.22^{\mathrm{ns}}$ & $2.20 \mathrm{~ns}$ & $7.52^{* *}$ & $8.54^{* *}$ & $2.64^{\mathrm{ns}}$ & $15.47^{\text {** }}$ & $12.45^{* *}$ \\
\hline Time & $3.87^{* *}$ & $1.99 \mathrm{~ns}$ & $1.09^{n s}$ & $1.40^{\mathrm{ns}}$ & $2.05^{\mathrm{ns}}$ & $4.63^{* *}$ & $3.76^{* *}$ \\
\hline $\mathrm{M} \times \mathrm{T}$ & $0.94^{\mathrm{ns}}$ & $0.73^{\mathrm{ns}}$ & $0.98^{\mathrm{ns}}$ & $0.79^{n s}$ & $1.16^{\mathrm{ns}}$ & $1.11^{\mathrm{ns}}$ & $0.96^{\mathrm{ns}}$ \\
\hline CV (\%) & 36.51 & 73.41 & 13.71 & 14.69 & 45.05 & 9.58 & 12.93 \\
\hline
\end{tabular}

(1) Labile Po, extracted with 0.5 mol L-1 $\mathrm{NaHCO}_{3}$ solution; (2) Moderately labile Po corresponds to the sum of Po extracted with $1.0 \mathrm{~mol} \mathrm{~L}-1 \mathrm{HCl}$ solution + fulvic acid Po; and (3) non-labile Po, corresponds to the sum of humic acid Po + residual Po. ns and $* *$ : non-significant and significant at $\mathrm{p}<0.01$, respectively. Means followed by the same letters do not differ by Tukey test ( $<<0.05)$. 
Po fractions (Table 3), as reported by Motavalli and Miles (2002) and Sharpley et al. (2004). The Po increase in these fractions might be the result of manure humification by microorganisms (Hedley et al., 1982), and these transformations are time-related. Nevertheless, time only affected the non-labile Po fraction, but the data had no defined trend and did not fit any regression equations (Table 3). At the time of manure application, part of manure Po was already present in moderately labile and non-labile forms (extracted with $\mathrm{NaOH}$ solution, Table 1), which were extracted together with the same Po forms from the soil, particularly in the beginning of the incubation process. Therefore, there was an increase of these Po forms in the soil samples at this time, as also reported by Sharpley and Moyer (2000), interfering with the evaluation of the time effect on Po transformations. Qian and Schoenau (2000) reported similar results when studying a single application of liquid swine manure, that is, the $\mathrm{P}$ added did not increase this element concentration in the more labile fractions, but entered the system as part of the moderately labile and non-labile fractions. Moreover, in this work, cattle manure was applied to a sandy-clay loam Haplustox, and according to Blake et al. (2003), this type of soil is more likely to accumulate stable forms of Po, even when no manure is added, whereas more sandy soils accumulate more labile Po forms.

In the extracts obtained with $\mathrm{NaOH}$ solution, $\mathrm{Po}$ forms such as fulvic acids predominated (Table 3). The fulvic acid Po quantity was approximately 4 -fold higher than the humic acid Po quantity, as observed by Schroeder and Kovar (2006). These authors reported that fulvic acid Po was the predominant Po form in the soil.

In soils treated with organic forms of $\mathrm{P}$, more stable forms of Po fractions are expected to accumulate, which was actually the case with the moderately labile and non-labile Po, extracted with $\mathrm{NaOH}$ solution, and with residual-P(Table 3). These fractions tend to decrease in non-fertilized soils, and under this condition, Beck and Sanchez (1994) observed that, in a Typic Paleudult, the fraction extracted with $\mathrm{NaOH}$ acted as major P source. In this fraction, humic and fulvic acids are the main constituents and the fulvic acids are more labile compounds and contain higher $\mathrm{P}$ concentrations (Ivanoff et al., 1998; Schroeder and Kovar, 2006). Finally, the residual fraction might act as $\mathrm{P}$ sink in systems treated with $\mathrm{P}$, mainly with fertilizers or residues (Ivanoff et al., 1998; Kashem et al., 2004; Hao et al., 2008). Thus, soils fertilized with excess $\mathrm{P}$, mainly as organic fertilizers, tend to accumulate non-labile $\mathrm{P}$, as occurred in plots treated with manure in this work (Table 3).

The $\mathrm{P}$ concentration increase in the moderately labile and non-labile Po fractions contributed to increase total Po (Table 4). This total Po increase was observed independently of the method used for Po determination (sum of fractions or incineration), but lower Po values were obtained with the incineration method for most soil samples (Table 4). The observed increase of organic $\mathrm{P}$ concentrations in plots treated with cattle manure was already expected and described by other authors (Sharpley et al., 2004; Hao et al., 2008), because $\mathrm{P}$ is a constituent of all manure types, despite the low concentrations.

Table 4. Total organic $P$ obtained by the sum of fractions and by incineration, determined in samples of a sandy-clay loam Haplustox fertilized or not with cattle manure, evaluated during 112 days of incubation

\begin{tabular}{|c|c|c|c|}
\hline Time & $\begin{array}{l}\text { Total Po } \\
\text { (sum) }^{(1)}\end{array}$ & $\begin{array}{c}\text { Total Po } \\
\text { (incineration)(2) }^{(2)}\end{array}$ & $\begin{array}{c}\text { Po sum } / \text { Po } \\
\text { incineration }\end{array}$ \\
\hline \multirow[t]{2}{*}{ day } & \multicolumn{2}{|c|}{$\mathrm{mg} \mathrm{kg-1}$} & $\%$ \\
\hline & \multicolumn{3}{|c|}{ Without manure } \\
\hline 3 & 102.8 & 108.2 & 95.1 \\
\hline 7 & 116.5 & 95.2 & 122.3 \\
\hline 14 & 114.7 & 86.0 & 133.4 \\
\hline 21 & 93.4 & 93.8 & 99.6 \\
\hline 28 & 110.5 & 103.0 & 107.3 \\
\hline 49 & 113.2 & 96.9 & 116.8 \\
\hline 70 & 111.6 & 85.3 & 130.8 \\
\hline 91 & 107.3 & 99.3 & 108.1 \\
\hline 112 & 108.3 & 95.5 & 113.4 \\
\hline \multirow[t]{2}{*}{ Mean } & $108.9 \mathrm{~b}$ & $95.9 \mathrm{~b}$ & 114.1 \\
\hline & \multicolumn{3}{|c|}{$20 \mathrm{t} \mathrm{ha}^{-1}$ manure } \\
\hline 3 & 113.4 & 104.4 & 108.6 \\
\hline 7 & 129.8 & 95.2 & 136.3 \\
\hline 14 & 125.7 & 90.4 & 139.0 \\
\hline 21 & 117.0 & 100.0 & 117.0 \\
\hline 28 & 117.8 & 100.0 & 117.8 \\
\hline 49 & 110.7 & 93.8 & 117.9 \\
\hline 70 & 123.6 & 89.4 & 138.2 \\
\hline 91 & 125.1 & 126.6 & 98.8 \\
\hline 112 & 118.5 & 110.6 & 107.2 \\
\hline \multirow[t]{2}{*}{ Mean } & $120.1 \mathrm{a}$ & $105.0 \mathrm{a}$ & 120.1 \\
\hline & \multicolumn{2}{|r|}{$\mathrm{F}$ test } & \\
\hline Manure & $18.86^{\star *}$ & $4.21^{*}$ & \\
\hline Time & $2.02^{\mathrm{ns}}$ & $1.15^{\mathrm{ns}}$ & \\
\hline $\mathrm{M} \times \mathrm{T}$ & $0.83^{\mathrm{ns}}$ & $0.79^{\mathrm{ns}}$ & \\
\hline CV (\%) & 9.70 & 18.74 & \\
\hline
\end{tabular}

(1) Total Po (sum) was obtained by the sum of fractions; (2) Total Po (incineration) was obtained by the method of combustion; $\mathrm{ns},{ }^{*}$ and $* *$ : non-significant, significant at $\mathrm{p}<0.05$ and $\mathrm{p}<0.01$, respectively. Means followed by the same letters do not differ by Tukey test (0.05). 
Table 5. Correlation coefficient ( $r$ ) values between $O M$ concentration, resin $P$ and the organic forms of $P$ (Po) in soil samples of a sandy-clay loam Haplustox fertilized or not with cattle manure, evaluated during 112 days of incubation

\begin{tabular}{|c|c|c|c|c|c|c|c|}
\hline & Resin P & OM & Labile Po & Mod Po & Non-labile Po & Total Po & Total P \\
\hline Resin $\mathrm{P}$ & - & $0.30^{\mathrm{ns}}$ & $0.26^{\mathrm{ns}}$ & $0.55^{* *}$ & $0.50^{* *}$ & $0.39^{\mathrm{ns}}$ & $0.67^{* * *}$ \\
\hline $\mathrm{OM}$ & & - & $0.34 \mathrm{~ns}$ & $0.07 \mathrm{~ns}$ & $0.12^{\mathrm{ns}}$ & $-0.10^{\mathrm{ns}}$ & $0.09 \mathrm{~ns}$ \\
\hline Labile Po & & & - & $0.15^{\mathrm{ns}}$ & $-0.19 \mathrm{~ns}$ & $0.25^{\mathrm{ns}}$ & $0.38^{\mathrm{ns}}$ \\
\hline Mod Po & & & & - & $0.29 \mathrm{~ns}$ & $0.21 \mathrm{~ns}$ & $0.69^{* * *}$ \\
\hline Non-lab Po & & & & & - & $0.14^{\mathrm{ns}}$ & $0.23^{\mathrm{ns}}$ \\
\hline Total Po & & & & & & - & $0.43^{*}$ \\
\hline Total P & & & & & & & - \\
\hline
\end{tabular}

$\mathrm{ns},{ }^{*},{ }^{* *}$, and ${ }^{* * *}$ : non-significant, significant at $\mathrm{p}<0.05, \mathrm{p}<0.01$ and $\mathrm{p}<0.001$, respectively.

The moderately labile $(44.4 \%$ of total $\mathrm{Po}$, on average) and non-labile Po forms (50.5\% of total Po, on average) predominated (Table 3 ), with little participation of labile Po (about $5.1 \%$ ). Although the manure application (20 t ha-1) increased the moderately labile and non-labile Po fractions and total $\mathrm{Po}$, this manure rate did not change the proportion among fractions. Schroeder and Kovar (2006) reported similar results, and commented that this is because no alterations in the $\mathrm{OM}$ concentrations occurred during the evaluation period inducing changes in the Po fraction proportions in relation to total Po. The labile fraction is the smallest part of total Po and the most variable fraction over time, because it is instable and subject to changes according to the management and soil-climatic conditions. The other Po fractions are more stable and resistant to alterations.

There was no correlation between Po fractions and OM (Table 5). Blake et al. (2003), studying a sandy soil with low organic $\mathrm{C}$ content, observed that $\mathrm{Po}$ represented the larger part of total $\mathrm{P}$, while in two medium texture soils (with 2.5-fold higher organic C) Po represented a small part of total $P$. This evidenced that other factors than OM content influences Po concentration (Blake et al., 2003; Darilek et al., 2010). In addition, there was no correlation between resin $\mathrm{P}$ and labile Po (Table 5), because the manure addition increased resin $\mathrm{P}$, but did not increase labile $\mathrm{Po}$, indicating that the soluble $\mathrm{Pi}$ forms in manure affected the plant-available $\mathrm{P}$ more than the labile Po forms. Although labile Po is the most available $\mathrm{P}$ form to plants, it is a small fraction of the soil total $\mathrm{Po}$, and thus, resin $\mathrm{P}$ and labile Po are rarely correlated with each other (Ivanoff et al., 1998). On the other hand, resin $\mathrm{P}$ was positively correlated with moderately labile $\mathrm{Po}$, non-labile Po and total Po (Table 5). These correlations appeared, because resin $\mathrm{P}$ and $\mathrm{Po}$ fractions increased with manure application, but generally with low correlation coefficients (r). Since the resin method extracts Pi, the correlations between resin $\mathrm{P}$ and Po should be negative when only Po is added to the soil, because one increases while the other decreases during the processes pf mineralization/immobilization. The positive correlations obtained can be explained by the simultaneous Pi and Po addition in cattle manure that resulted in higher available $\mathrm{Pi}$ (resin $\mathrm{P}$ ) and higher stable Po concentrations. Schroeder and Kovar (2006) observed negative correlations between available $\mathrm{Pi}$ and more stable Po forms, and obtained $\mathrm{r}$ values of $-0.84^{*},-0.97^{* *}$ and $-0.97^{* *}$ for the correlations between humic acid non-labile Po $\times$ labile-Pi extracted with $\mathrm{NaHCO}_{3}$, fulvic acid $\mathrm{Po}$ and $\mathrm{Al}-\mathrm{Pi}$, respectively.

Total $\mathrm{P}$ correlated with total $\mathrm{Po}$ and with moderately labile Po (Table 5). This correlation was expected since these fractions represented a large part of soil total P. Schroeder and Kovar (2006) commented that moderately labile and non-labile Po fractions usually have high correlations with total $\mathrm{P}$ and total Po, and tend to increase as management procedures to increase soil $\mathrm{OM}$ and total $\mathrm{P}$ are adopted. In this work, manure addition did not increase the soil OM content, but caused increases in total P (Table 2) and total Po concentrations (Table 4).

\section{CONCLUSIONS}

Cattle manure application increased the moderately labile Po and non-labile Po fractions and total Po, and did not interfere with Po fraction proportions in relation to total Po.

The more soluble Pi forms in the manure influenced plant-available $\mathrm{P}$ more than the labile Po forms.

The labile and non-labile Po fractions varied over the sampling time, but no defined tendency was detected.

\section{REFERENCES}

Alcarde JC. Manual de análises de fertilizantes. Piracicaba: Fundação de Estudos Agrários Luiz de Queiroz; 2009. 
Andrade FV, Mendonça ES, Alvarez V VH, Novais RF. Adição de ácidos orgânicos e húmicos em Latossolos e adsorção de fosfato. R Bras Ci Solo. 2003;27:1003-11.

Beck MA, Sanchez PA. Soil phosphorus fractions dynamics during 18 years of cultivation on a typic Paleudult. Soil Sci Soc Am J. 1994;58:1424-31.

Blake L, Johnston AE, Poulton PR, Goulding KWT. Changes in soil phosphorus fractions following positive and negative phosphorus balances for long periods. Plant Soil. 2003;254:245-61.

Bowman RA, Cole CV. An exploratory method for fractionation of organic phosphorus from grassland soil. Soil Sci. 1978;125:95-101.

Camargo AO, Moniz AC, Jorge JA, Valadares JMAS. Métodos de análise química, mineralógica e física de solos do Instituto Agronômico de Campinas. Campinas: Instituto Agronômico; 2009. (Boletim técnico, 106).

Chen GC, He ZL, Huang CY. Microbial biomass phosphorus and its significance in predicting phosphorus availability in red soils. Commun Soil Sci Plant Anal. 2000;31:655-67.

Conte E, Anghinoni I, Rheinheimer DS. Fósforo da biomassa microbiana e atividade de fosfatase ácida após aplicações de fosfato em solo no sistema plantio direto. R Bras Ci Solo. 2002;26:925-30.

Darch T, Blackwell MSA, Hawkins JMB, Haygarth PM, Chadwick D. A meta-analysis of organic and inorganic phosphorus in organic fertilizers, soils and water: implications for water quality. Crit Rev Environ Sci Technol. 2014;44:2172-202.

Darilek JL, Huang B, Li DC, Wang ZG, Zhao YC, Sum WX, Shi $\mathrm{XZ}$. Effect of land use conversion from rice paddies to vegetable fields on soil phosphorus fractions. Pedosphere. 2010;20:137-45.

Dou Z, Toth JD, Galligan DT, Ramberg Jr CF, Ferguson JD. Laboratory procedures for characterizing manure phosphorus. J Environ Qual. 2000;29:508-14.

Eghball B. Soil properties as influenced by phosphorus- and nitrogen- based manure and compost applications. Agron J. 2002;94:128-35.

Gatiboni LC, Kaminski J, Santos DR. Modificações nas formas de fósforo do solo após extrações sucessivas com Mehlich-1, Mehlich-3 e resina trocadora de ânions. R Bras Ci Solo. 2005;29:363-71.

Griffin TS, Honeycutt CW, He Z. Changes in soil phosphorus from manure application. Soil Sci Soc Am J. 2003;67:645-53.

Guppy CN, Menzies NW, Moody PW, Blamey FPC. Competitive sorption reaction between phosphorus and organic matter: a review. Aust J Soil Res. 2005;43:189-202.

Hao X, Godlinski F, Chang C. Distribution of phosphorus forms in soil following long-term continuous and discontinuous cattle manure applications. Soil Sci Soc Am J. 2008;72:90-7.

Hedley MJ, Stewart JWB, Chauhan BS. Changes in inorganic and organic soil phosphorus fractions induced by cultivation practices and by laboratory incubations. Soil Sci Soc Am J. 1982;46:970-6.

Hue NV, Ikawa H, Silva JA. Increasing plant-availability phosphorus in an Ultisol with a yard-waste compost. Commun Soil Sci Plant Anal. 1994;20:3291-303.

Ivanoff DB, Reddy KR, Robinson S. Chemical fractionation of organic phosphorus in selected Histosols. Soil Sci. 1998;163:36-45.
Kashem A, Akinremi OO, Racz GJ. Phosphorus fractions in soil amended with organic and inorganic phosphorus sources. Can J Soil Sci. 2004;84:83-90.

Kovar JL, Pierzynski GM. Methods of phosphorus analysis for soils, sediments, residuals, and waters. $2^{\mathrm{a}}$ ed. Virginia: Virginia Tech University Press; 2009. (Southern Cooperative Series Bulletin, 408).

Kuo S. Phosphorus. In: Sparks DL, editor. Methods of soil analysis: Chemical methods. Madison: Soil Science Society of America; 1996. Part 3. p.869-920.

Machado MICS, Brauner JL, Vianna ACT. Formas de fósforo na camada arável de solos do Rio Grande do Sul. R Bras Ci Solo. 1993;17:331-6.

Maillard E, Angers DA. Animal manure application and soil organic carbon stocks: A meta-analysis. Global Change Biol. 2014;20:666-79.

Motavalli PP, Miles RJ. Soil phosphorus fractions after 111 years of animal manure and fertilizer applications. Biol Fertil Soils. 2002;36:35-42.

Murphy J, Riley JP. A modified single solution method for the determination of phosphate in natural waters. Anal Chim Acta. 1962;27:31-6.

Pagliari PH, Laboski CAM. Investigation of the inorganic and organic phosphorus forms in animal manure. J Environ Qual. 2012;41:901-10.

Qian P, Schoenau JJ. Fractionation of P in soil as influenced by a single addition of liquid swine manure. Can J Soil Sci. 2000;80:561-6.

Raij BV, Andrade JC, Cantarella H, Quaggio JA, editores. Análise química para avaliação da fertilidade de solos tropicais. Campinas: Instituto Agronômico; 2001.

Schjønning P, Christensen BT, Carstensen B. Physical and chemical properties of a sandy loam receiving animal manure, mineral fertilizer or no fertilizer for 90 years. Eur J Soil Sci. 1994;45:257-68.

Schroeder PD, Kovar JL. Comparison of organic and inorganic phosphorus fractions in an established buffer and adjacent production field. Commun Soil Sci Plant Anal. 2006;37:1219-32.

Sharpley AN, McDowell RW, Kleinnman JA. Amounts, forms, and solubility of phosphorus in soils receiving manure. Soil Sci Soc Am J. 2004;68:2048-57.

Sharpley AN, Moyer B. Phosphorus forms in manure and compost and their release during simulated rainfall. J Environ Qual. 2000;29:1462-9.

Sharpley AN, Sisak I. Differential availability of manure and inorganic sources of phosphorus in soil. Soil Sci Soc Am J. 1997;61:1503-8.

Turner BL, Engelbrecht BMJ. Soil organic phosphorus in lowland tropical forests. Biogeochemistry. 2011;103:297-315.

Viaud V, Angers DA, Parnaudeau V, Morvan T, Menasseri Aubry S. Response of organic matter to reduce tillage and animal manure in a temperate loamy soil. Soil Use Manage. 2011;27:84-93.

Vincent AG, Turner BL, Tanner EVJ. Soil organic phosphorus dynamics following perturbation of litter cycling in a tropical moist forest. Eur J Soil Sci. 2010;61:48-57. 
Whalen JK, Chang C, Clayton GW, Carefoot JP. Cattle manure amendments can increase the $\mathrm{pH}$ of acid soils. Soil Sci Soc Am J. 2000;64:962-6.

Yagi R, Ferreira ME, Cruz MCP, Barbosa JC. Organic matter fractions and soil fertility under the influence of liming, vermicompost and cattle manure. Sci Agric. 2003;60:549-57.
Yan F, Schubert S, Mengel K. Soil pH increase due to biological decarboxilation of organic anions. Soil Biol Biochem. 1996;28:617-24.

Yang X, Post WM. Phosphorus transformations as a function of pedogenesis: A synthesis of soil phosphorus data using Hedley fractionation method. Biogeosciences. 2011;8:2907-16. 